\title{
The New Partnership Approach in the 2003 Belgium- Netherlands Tax Treaty
}

\author{
Gijsbert Fibbe and Mathieu Isenbaert*
}

\section{Introduction}

Since 1 January 2003, a new double tax Treaty is applicable between Belgium and the Netherlands. The old Treaty of 1970 already included a specific provision relating to partnerships. Including three distinct provisions has now expanded the tradition and it is the objective of this expose to examine these provisions in their domestic and international context. For that purpose, we will first outline the general approach under the previous Treaty and under the OECD Commentary. Next, we will place the domestic classification rules for foreign entities of each Contracting State under scrutiny and apply them to the other State's partnerships. Finally, we will examine the specific partnership provisions of the new Treaty by analysing the examples given in the Joint Explanatory Notes. Evidently, reference will be made to the treatment of analogue situations suggested by the OECD Partnership Report. As the provisions seem to overlap to some extent, we have also contemplated the nature of their interrelationship.

2. The partnership approach under the Belgium-Netherlands 1970 tax Treaty

According to Art. 4, Para. 1, of the Belgium-Nether-

\section{Notes}

* Mathieu Isenbaert is a Ph.D. candidate at the Faculty of Law of the Catholic University Leuven and a tax lawyer at Baker \& McKenzie in Brussels, Gijsbert Fibbe is a Ph.D. student at the Faculty of Law of the Erasmus University Rotterdam and a tax consultant at PricewaterhouseCoopers in Rotterdam. The authors would like to thank Prof. F. Vanistendael for his review and comments. 
lands tax Treaty of 1970 (hereinafter: the 1970 tax Treaty), the Dutch civil law partnership, the Dutch general partnership and the Dutch limited partnership, the place of effective management of which is situated in the Netherlands, are considered Treaty residents. Furthermore, Art. 3, Para. 1, subpart 2, of the 1970 tax Treaty explicitly mentions that those partnerships are considered persons. ${ }^{1}$ Consequently, a Dutch partnership is entitled to claim the benefits of the Treaty, despite the fact that under Dutch tax law partnerships are treated as transparent. ${ }^{2}$ This is a remarkable deviation of the other tax treaties concluded by the Netherlands. ${ }^{3}$ Neither in Belgium nor in the Netherlands an explanation for the created Treaty residency of aforementioned partnerships has been provided. ${ }^{4}$

\section{The OECD partnership approach}

As of July 2000, several paragraphs of the OECD Commentary make reference to classification conflicts. In case of a different classification of an entity, the OECD Commentary suggests that the State of Source should take into account, as part of the factual context in which the convention is to be applied, the way in which an item of income arising in its jurisdiction is treated in the jurisdiction of the person claiming the benefits of the convention as a resident. ${ }^{5}$ The classification of the entity in the State of Residence will be decisive. ${ }^{6}$ Moreover, the Commentary states that where the income has flowed through the partnership to the partners, the income should be viewed as 'paid' to the partners. ${ }^{7}$ Therefore, if the partnership does not qualify as a resident, the partners are the appropriate persons to claim the benefits of the Convention in the State where they are resident to the extent they are liable to tax on their share of the income. In the absence of such interpretation, the Treaty benefits could not be claimed as the partnership would not be considered a resident on the one hand and the partners would not be regarded as the direct recipients of the income on the other hand.
Despite a common classification of an entity, characterization conflicts may still occur with respect to the nature of an item of income. The Contracting States may indeed disagree on which allocative provision is relevant, again owing to differences in their respective domestic laws. This can result in double taxation or double non-taxation. In this case the OECD Commentary considers that when the State of Residence applies Art. 23 of the OECD Model, the phrase '... in accordance with the provisions of this Convention, may be taxed in the other Contracting State...' is still applicable to that item of income as interpreted and applied by the State of Source. ${ }^{8}$ This means that the State of Residence is required to follow the characterization of the State of Source and apply the exemption or credit method accordingly. ${ }^{9}$ Following this clarification, the characterization conflict is resolved by the obligation of the State of Residence to grant relief from double taxation pursuant to Art. 23 of the OECD Model.

In this respect, it should be noted that the Netherlands, as opposed to Belgium, has made an observation on the Commentary to Art. 1 and the Commentary to Articles 23A and 23B. ${ }^{10}$ The Netherlands will only adhere to abovementioned interpretation if it is explicitly confirmed in a specific tax Treaty or if it is the result of a mutual agreement procedure or unilateral policy. At the time this observation was made, the Netherlands was already negotiating the 2003 Belgium-Netherlands tax Treaty.

\section{Potential classification conflicts between Belgium and the Netherlands}

\section{A. Notes of the Treaty partners}

Already in the 1970 Treaty, the two countries were aware of the problems a different classification of entities could create. The Joint Explanatory Notes ${ }^{11}$

\section{Notes}

Which is similar to the (current) OECD approach, see Para. 2 of the revised 2000 Commentary to Art. 3 of the OECD Model.

2 Unless it concerns a partnership with a capital divided into shares (see Supreme Court 24 November 1967, BNB 1978/13) as meant in art. 2, para. 1, part a, Corporate Income Tax Act 1969 or a shared fund as meant in art. 2, para. 2, Corporate Income Tax Act 1969 or an 'open' limited partnership as meant in art. 2, para. 1, part a, Corporate Income Tax Act 1969 and defined in art. 2, para. 3, part c, General Tax Act 1959.

3 Also C. van Raad in his annotation under the decision of the Supreme Court of 23 March 1994, FED 1994/298.

4 Some authors thought that it might have to do with the Belgium domestic treatment of foreign entities at that time as until 1989, under Belgium tax law, any nonresident entity was treated as a foreign corporation for Belgian domestic tax purposes. See A.H.M. Daniëls, Issues in International Partnership Taxation, Series on International Taxation vol. 12, Kluwer Law and Taxation Publishers, Deventer/Boston, 1991, p. 210-211.

5 Para. 6.3 of the revised 2000 Commentary to Art. 1 of the OECD Model.

6 This solution was founded on the 1999 OECD Report 'The Application of the OECD Model Tax Convention to Partnerships' (hereinafter: the Report). See a.o. Para. 53 of the Report.

Para. 6.4 of the revised 2000 Commentary to Art. 1 of the OECD Model.

8 Para. 32.3 of the revised 2000 Commentary to Art. 23A and B of the OECD Model. See also Para. 104 and 105 of the Report.

9 For a discussion of this interpretation we refer to F.A. Engelen and P.G. Pötgens, Report on 'The Application of the OECD Model Tax Convention to Partnerships' and the Interpretation of Tax Treaties, European Taxation, July 2000, p. 261-265.

10 Para. 27.1 of the revised 2000 Commentary to Art. 1 of the OECD Model and Para. 80 of the revised 2000 Commentary to Art. 23A and 23B of the OECD Model.

11 In Belgium: Gezamenlijke Memorie van Toelichting, Belgische Senaat, 21 november 2002, 2-1293/2. In the Netherlands: Kamerstukken II, 2001-2002, 28259, nr. 3 p. $22-23$. 
(hereinafter: the Notes) of the new Treaty elaborate on that subject by listing the entities that are at risk of a hybrid classification and by exemplifying the relevant Protocol provisions. According to the Notes, a classification conflict arises with respect to civil law partnerships ('maatschappen'), general partnerships ('vennootschappen onder firma'), limited partnerships ('commanditaire vennootschappen') and (Belgian) temporary partnerships ('tijdelijke verenigingen'). A problem with this enumeration is that both countries use the same Dutch names for these entities so that it is not clear whether the Belgian or Netherlands entity is concerned or both. The only company used as an example in the Notes, is a Dutch general partnership.

\section{B. Belgian classification of foreign entities}

\section{The general principles}

According to article $2, \mathbb{2}$ of the Belgian Income Tax Code (hereinafter: ITC) only legal persons can be subject to corporate taxation. Legal personality is awarded by the Company Code. ${ }^{12}$ As tax law follows civil law, legal personality will principally be recognized for tax purposes to the extent tax law does not explicitly deviate from civil law. ${ }^{13}$ Belgian tax law only does so in a very limited number of cases. ${ }^{14}$

In defining 'companies', the Belgian ITC does not distinguish between domestic and foreign companies. Therefore, a foreign entity has to be a legal person in order to qualify for company taxation in Belgium. The legal personality of a foreign company is determined by the law of its seat of management (lex societatis). ${ }^{15}$ Again, Belgian tax law will follow the foreign company law characterization, even if the foreign tax law provides for fiscal transparency. ${ }^{16}$ The leading case in this respect is the 'Prince de Ligne' judgment. ${ }^{17}$ It concerns a Belgian resident who participates in a French 'société civile immobilière' ('civil real estate company'). According to French law, this company is a legal person, yet subjected to fiscal transparency according to articles 8 and 60 of the French Code Général des Impôts ('C.G.I.'). The Belgian tax administration characterized the income derived from the 'société civile immobilière' as immoveable income of the Belgian resident since it was constituted entirely out of rents paid. The Court of Appeal did not concur as Belgian law is to respect the legal personality awarded by French law. Yet the foreign tax transparency cannot be upheld in Belgium as the Belgian Court and administration are only competent to apply Belgian tax law. The Court concludes that the income derived by the Belgian partner in the French 'société civile immobilière' is taxable in Belgium as income from moveable goods (income from dividends).

In a single provision ${ }^{18}$ only, Belgian tax law derogates from this general approach to foreign entities. Article $227,2^{\circ}$ ITC provides that foreign associations, institutions or entities without legal personality but established in a legal form comparable to the legal form of a company according to Belgian law, falls within the scope of the non-resident taxation. In other words, for Belgium-sourced income tax purposes, a foreign entity without legal personality can nevertheless be treated by Belgian tax law as opaque on the condition it is similar to a Belgian company. This comparability is very difficult to assess and no guidance is provided in the Administrative Commentary. ${ }^{19}$ A comparison with the Belgian general and limited partnerships can be interesting as they both have legal personality and at the same time have the characteristics of a partnership. On this basis, it is suggested that a Dutch general partnership and a German 'Offene Handelsgesellshaft' are such comparable entities and should therefore be considered as opaque for Belgian non-resident taxation purposes. ${ }^{20}$

\section{Notes}

12 S. Van Crombrugge, Beginselen van de vennootschapsbelasting, Biblo, 1999, p. 13 with refernce to A. Mast and J. Dujardin, Overzicht van het Belgisch administratief recht, Gent, Story-Scientia, 1984, nr. 44.

13 C. Chevalier, Vademecum vennootschapsbelasting, Larcier, 2001, p. 4.

14 Only five Belgian entities with legal personality are considered fiscally transparent. None of these entities qualify as partnerships or are regularly used for business purposes, if allowed at all. The entities are: the agricultural company ('landbouwvennootschap', 'sociéte agricole') that has opted for fiscal transparency (article 29, $\$ 2,2^{\circ}$ ITC), the Economic Interest Grouping and the European Economic interest Grouping (article 29, $\$ 2,3^{\circ}$ and $4^{\circ}$ ITC), the associations of co-owners ('vereniging van mede-eigenaars') (article $29, \$ 2,5^{\circ}$ of the ITC) and finally the 'civil forestry clustering company' ('burgerlijke bosgroeperingsvennootschap'), article 3 of the Law of $6^{\text {th }}$ May 1999.

15 Contrary to the Netherlands, Belgium does not follow the state of incorporation doctrine with regard to foreign entity characterization. G. Van Hecke en K. Lenaerts, Beginselen van internationaal privaatrecht, Gent, Story-Scientia, 1989, nr. 742; J. Erauw, Belgisch Internationaal privaatrecht, Ghent University Press, 2000, Book II, p. 305.

16 J.-P. Lagae, Vennootschapsbelasting, ced.samsom, 1998, nr. 13; with reference to Brussel, 4 June 1974, J.D.F., 1975, 82 (arrest Prince de Ligne); Th. Afschrift, "La constitution d'une personne morale de droit étranger dans l'unique but d'éluder l'impôt belge", in Mélanges offerts à R. Van der Elst, Brussel, Memeris, 1986, p. 2742; P. De Page en B. Van de Walle de Gelcke, "Les personnes morales étrangères et l'ordre public international belge", Rev. Prat. Soc., 1979, nr. 6002; J. Erauw, Beginselen van het internationaal privaatrecht, Gent, Story-Scientia, 1985, p. 257 e.v.; L. Hinnekens, "Basisvennootschappen en brievenbusvennootschappen in het Belgische belastingrecht", A.F.T., 1983, p. 80 e.v.; L. Hinnekens, De territorialiteit van de Belgische belastingen in het algemeen en op de inkomsten in het bijzonder, Brussel, Ced.Samsom, 1985, p. 76 e.v.; J.P. Lagae, "L'utilisation de sociétés étrangères par des résidents belges en vue d'éviter l'impôt belge", in L'entreprise et le choix de la voie la moins imposée en droit fiscal belge, Brussel, Ed. Jeune Barreau, 1988, p. 201; K. Debrier, 'Hybrid entities from a Belgian perspective', Bull. IBFD, 1996/6, 306.

17 Court of Appeal of Brussels, 4 June 1974, J.D.F., 1975, p. 82.

18 In the definition of the scope of the non-resident taxation, articles 227-248 ITC.

19 The Belgian administrative commentary even ignores the wording of this provision, Com.Ib. 227/35.

20 S. Van Crombrugge, Internationaal Fiscaal Recht, Ghent University Press, 2001, p. 19. 


\section{Belgian classification of Netherlands partnerships}

Netherlands company law does not assign legal personality to the Netherlands general partnership ('v.o.f.') and neither to a limited partnership ${ }^{21}$ ('c.v.'). ${ }^{22}$ The Belgian classification of these two entities is heavily disputed. In a question regarding the accounting treatment of participations in a Dutch c.v., the Belgian Commission for Accounting Standards (hereinafter: C.A.S.) $)^{23}$ was asked to rule on the Belgian status of this entity. ${ }^{24}$ It is implied that the Dutch c.v. is located and managed in the Netherlands. The C.A.S. pointed out that Belgian law ('lex fori') will determine the classification of the foreign entity. While the C.A.S. acknowledges that the c.v. does not have legal personality in the Netherlands, it is able to discern several characteristics that are reserved to legal persons in Belgium. The C.A.S. points out that the entity acts in its own name and for its own account, to a certain extent has assets and liabilities separate from their partners, has active and passive legal standing, can be declared bankrupt and finally has a kind of 'bound coownership' in the interest of external stakeholders. ${ }^{25}$ Consequently, the C.A.S. holds that the contributions should be treated as participations in companies. As Belgian tax law should abide by this civil law characterization, the Dutch c.v. and the very similar Dutch v.o.f. will be regarded as opaque from the Belgian tax law perspective. The tax authorities negotiating the Treaty conclude similarly in the Notes. Van Crombrugge shares this opinion without further reservations. ${ }^{26}$ Haelterman however contends that the absence of Dutch legal personality will be respected by Belgian tax law. ${ }^{27}$ This reasoning is followed by De
Broe $^{28}$ en Heyvaert. ${ }^{29}$ De Broe in particular objects to the use of the Belgian legal perspective ('lex fori'). ${ }^{30} \mathrm{He}$ contends that the question of legal personality should be solved according to the country of seat of management ('lex societatis'), being the Netherlands. This leads De Broe to the conclusion that the Dutch c.v. also from a Belgian perspective should be considered transparent.

In our view, it is indeed irrelevant whether the Dutch c.v. has properties that are unique to legal persons in Belgium. By trying to determine how Belgian law would regard an entity with the characteristics of the Dutch c.v., the C.A.S. ignores the Belgian rules of international private law. The entire classification issue should be resolved exclusively from the perspective of the country where the central management is located ('lex societatis'), ${ }^{31}$ being the Netherlands in the case at hand. In doing so, Belgium should not substitute the Dutch concept of 'legal personality' with its domestic concept. ${ }^{32}$ We therefore concur with the majority of legal scholars that a Dutch v.o.f. and c.v. are to be considered transparent from the Belgian perspective.

The classification of a Netherlands civil law partnership ('maatschap') however does not create any specific problems with respect to the Belgian general principles. Dutch company law does not award the 'maatschap' any of the abovementioned characteristics typical to Belgian legal personality. Even according to the abovementioned reasoning of the C.A.S. and the tax administration, the entity clearly is to be considered transparent from the Belgian perspective also.

\section{Notes}

21 'vennootschap onder firma' and 'commanditaire vennootschap' respectively. The concept of an 'open' commanditaire vennootschap is a tax concept only and does not relate to the disclosed character of the partnership. An 'open' commanditaire vennootschap, although not granted legal personality, is treated as opaque for Dutch taxation purposes when the partnerships interests are freely transferable.

22 It should be noted however that a proposed Bill provides for the possibiltiy for v.o.f.'s and c.v.'s to opt for legal personality; Kamerstukken II $2002 / 03$, nr. 28746 , nr. 1 and 2. The Minister of Finance has stated that this would not influence the fiscal transparency.

23 In Dutch: 'Commissie voor Boekhoudkundige Normen, C.B.N.', in French: 'Commission des Normes Comptables, C.N.C.'

24 Commissie voor Boekhoudkundige Normen, Bull. C.B.N., 168/1, december 1993, nr. 31, p. 32.

25 The C.A.S. refers to K.W. Heyman, 'Van B.V. naar C.V.', De commanditaire vennootschap in de actuele praktijk, Kluwer, Deventer, 1988, p. 16/24; J.F.M. Giele, De commanditaire vennootschap, Kluwer, Deventer, 1987, p. 25.

26 S. Van Crombrugge, 'Deelnemingen in buitenlandse vennootschappen zonder rechtspersoonlijkheid', Fiskoloog, 1994 , nr. 456, p. 4.

27 A. Haelterman, Fiscale Transparantie, Biblo, 1992, p. 453, nr. 570.

28 L. De Broe, 'Nederlandse en Duitse commanditaire vennootschappen: fiscale consequenties van een twijfelachtig advies van de Commissie voor Boekhoudkundige Normen', T.R.V., 1995, p. 38.

29 W. Heyvaert, 'Artikel 4: Inwoners', in Het nieuwe Belgisch-Nederlandse dubbelbelastingverdrag, B. Peeters (ed.), Larcier Gent, 2001, nr. 4.20.

30 L. De Broe, 'Nederlandse en Duitse commanditaire vennootschappen: fiscale consequenties van een twijfelachtig advies van de Commissie voor Boekhoudkundige Normen', T.R.V., 1995, p. 38.

31 G. Van Hecke en K. Lenaerts, Beginselen van internationaal privaatrecht, Gent, Story-Scientia, 1989, nr. 742; J. Erauw, Belgisch Internationaal privaatrecht, Ghent University Press, 2000, Book II, p. 305; J. Van Rijn en J. Heenen, Principes de droit commercial, II, Brussel, Bruylant, 1958, 1130; F. Bouckaert, 'Overzicht van rechtspraak internationaal privaatrecht (1965-84) - Vennootschappen', TPR, 1984, 1489-1490.

32 This reasoning is of course only valid from a Belgian perspective as long as the other Contracting State clearly awards or denounces 'legal personality' to the entity in question. In the absence of such a clear classification by the lex societatis, there is no alternative but to analyze the characteristics awarded by the lex societatis to the foreign entity according to Belgian law (lex fori). This was the case with regard to a U.S. general partnership in Court of Appeal of Brussels, April 30, 1998, A.F.T., March 1999, with note A. Van De Vijver, p.119-124. U.S. domestic law does not allow determining clearly whether general and limited partnerships have legal personality, so that the Court could only fall back on the domestic concept (lex fori). We contend with Van De Vijver that this was the right solution. However, in the case at hand it is clear that, according to Netherlands civil law, Dutch general (and limited) partnerships are transparent. Hence, referring to the lex fori does not become a necessity and the prohibition by Belgian international private law not to do so, stands. 


\section{Dutch classification of foreign entities}

\section{The general principles}

In determining the transparent or opaque nature of a foreign entity, the crucial element for the Dutch Supreme Court seems to be whether the partners are directly entitled to the profits of the entity. ${ }^{33}$ Dutch international private law provides that this has to be determined according to the characteristics of the entity under the applicable foreign law, ${ }^{34}$ which is the law of incorporation or establishment of the foreign entity. ${ }^{35}$ Parallel to Belgium, the classification for Dutch taxation purposes is done autonomously, meaning that the classification under foreign tax law is irrelevant. ${ }^{36}$ In 1997 the Dutch tax administration issued a Decree that outlined the criteria determining, in their view, whether a foreign entity should be treated as transparent or opaque. ${ }^{37}$ The Decree was issued in the framework of the participation exemption and is to be applied where the Netherlands is the residence state of the partners. The criteria are the following: ${ }^{38}$

(i) Is a resolution required to distribute the entity's profits to the participants?

(ii) Is the participant's liability limited to the capital contribution?

(iii) Is the entity the legal owner of the assets used for conducting the business operations?

(iv) Can the participants freely transfer their interest in the entity?

(v) Is the entity's capital divided into shares?

(vi) Is the entity subject to tax in the state where it is resident?

Both the articles of association of the foreign entity as well as the applicable foreign company law are to be taken into consideration when assessing these criteria. If all criteria are met, the entity is considered opaque for Dutch taxation purposes. In the large majority of cases however, the foreign entity will not meet all the criteria. In that instance, the entities are considered hybrid and further tests are provided. The Decree divides those hybrids in limited partnerships on the one hand and hybrid entities on the other. An entity will be regarded as a limited partnership provided (i) that the liability of the limited partners is limited to their capital contributions, (ii) that the limited partnership is not the legal bearer of the rights and obligations of the conducted business activities and (iii) that the general partner legally owns the assets used for conducting the partnership's business. Subsequently, such a limited partnership will be regarded as opaque for Dutch taxation purposes if the participation in the entity is freely transferable and as transparent if otherwise. This rather restrictive criterion is based on the features of a Dutch 'open' limited partnership of which the interests should be transferable without the consent of all partners. This 'open' limited partnership is treated as opaque for Dutch taxation purposes.

In order to determine whether hybrid entities other than limited partnerships should be treated as transparent or opaque, the Decree ${ }^{39}$ provides further criteria. The first element is whether either the partners or the entity are the legal owners of the assets used for the entity's business. In the situation where the partners are the legal owners of the assets, the entity will be considered transparent for Dutch taxation purposes. In the opposite situation, the entity will normally be regarded as opaque. However, even when the entity legally owns the business assets, it may still be treated as transparent under the condition that the business is conducted for the risk and account of the participants and the participants are directly entitled to the entity's profits. The latter will be the case when no resolution is required to distribute the profits to the participants. ${ }^{40}$

\section{Dutch classification of Belgian partnerships}

The 'maatschap' or 'société de droit commun' (the Belgian civil law partnership, hereinafter: s.d.c.) ${ }^{41}$ does not meet any of the six tests. Since the s.d.c. has no legal personality ${ }^{42}$ and none of the partners have

\section{Notes}

33 See Supreme Court 31 December 1924, B. 3569 with respect to the classification of a German Offene Handelsgesellschaft and Supreme Court 7 June 1939 , B. 6925 with respect to a French société à responsabilité limitée.

34 See Supreme Court 10 June 1953, BNB 1953/204 and Supreme Court 18 February 1959, BNB 1959/124.

35 Based on art. 2 of the Conflict laws for Corporations. In opposition to Belgium, under the Dutch rules of international private law, the foreign entity is controlled by the laws under which it is incorporated. See also J.W. Bellingwout, Fiscale aspecten van het wetsvoorstel conflictenrecht corporaties, WFR $1996 / 372$, p. 373.

36 High Court 14 July 1981, BNB 1982/264 and High Court 18 March 1992, nr. 89/1926, V-N 1992 at 1884.

37 Decree of 18 September 1997, no. DGO97/00417, see also the Decree of 19 December 2000, no. CPP2000/2175M.

38 For a discussion on the Decree see T. Bender and A.J.A. Stevens, Enkele kanttekeningen bij het Besluit fiscale kwalificatie inkomensstromen uit buitenlandse samenwerkingsverbanden, WFR 1998/6276, p. 97 and F.A. Engelen, Kwalificatie van buitenlandse samenwerkingsverbanden en de verdragstoepassing bij kwalificatieverschillen tussen Nederland en een ander land, MBB 1998/203, p. 203 and F. Engelen and H. Schröder, Dutch Taxation of Income Derived from Foreign Partnerships, Intertax, 1998, p. 178.

39 With specific reference to the French Société en Nom Collectif (hereinafter: SNC).

40 Also the limited liability of the partners is mentioned as a requirement in this respect. However, later on in the Decree, only the ownership of the assets and the requirement of a resolution to distribute the profits seem decisive.

41 The Netherlands and Belgian denominations (in Dutch) of the partnerships are almost identical. We will therefore use the abbreviations in French when referring to the Belgian partnerships.

42 Art. 46 Belgian Company Code. 
limited liability, ${ }^{43}$ it obviously cannot constitute a limited partnership under the Decree. Its lack of legal personality also prevents it from owning the assets of the business and company law does not require a resolution to distribute profits. ${ }^{44}$ Hence, under Netherlands tax law and parallel to the Belgian treatment, the s.d.c. will be regarded as transparent.

The 'vennootschap onder firma' or 'société en nom collectif' (hereinafter: s.n.c.) can be considered to be the Belgian general partnership. The only company law difference with the limited partnership ('gewone commanditaire vennootschap' or 'société en commandite simple', hereinafter: s.c.s.), is that the s.c.s. can have partners with limited liability ${ }^{45}$ whereas all the partners in the s.n.c. have joint unlimited liability. ${ }^{46}$ The Dutch classification of these two entities for Dutch taxation purposes is disputed in literature. De Vries and Sillevis are of the opinion that the Belgian s.n.c. should be classified as transparent for Dutch taxation purposes. Despite the fact that the s.n.c. has legal personality, they state that the partners are directly entitled to the profits. ${ }^{47}$ This reasoning is followed by Van Waardenburg $^{48}$ and Van Keulen. ${ }^{49}$ On the other hand, Siebens states that due to the legal personality of the s.n.c., the partners are not directly entitled to the profits and the s.n.c. should be regarded as opaque for Dutch taxation purposes. ${ }^{50}$

Under abovementioned Decree, the two partnerships will not satisfy all six tests for the reason that their partners do not have limited liability, except for the limited partners in the s.c.s. It will also depend on the partnership contract whether the interests are transferable without the consent of the other partners. ${ }^{51}$ Under the Decree, the s.c.s. (and s.n.c.) equally do not qualify as a Netherlands limited partnership since the assets are not owned by the general partner and the entity does have rights and liabilities of its own because of its legal personality. ${ }^{52}$ For the same reason, the s.n.c. and the s.c.s. are the legal owner of the assets used for conducting the business activities. In the end, the s.c.s and s.n.c. will be considered opaque when a resolution is required to distribute the profits to the participants. Such a decision on the company level is indeed required by Belgian company law. ${ }^{53}$ Conse- quently and notwithstanding the unlimited liability of some partners, both entities should be regarded as opaque under the Decree. ${ }^{54}$ This would bring their Netherlands treatment in line with their Belgian treatment.

\section{The new Treaty partnership provisions}

\section{A. Initiative of the Contracting States (Art. 2, Protocol I)}

\section{The Protocol provision}

Art. 2, Protocol I, of the new Treaty provides that if a company is subject to tax as such in one Contracting State, yet the income or the assets of that company are taxed as income or assets of the participants in that company in the other Contracting State, the Treaty provisions cannot have as a consequence that double taxation or a complete or partial exemption of the income or the assets continues. In order to avoid such a consequence, the tax, income and assets of the company are deemed to be tax, income and assets of the participants of that company proportionate to their entitlement to the assets of the company. The third sentence provides that double taxation can be avoided by (i) the other State giving a credit for the tax on the income or assets levied by the first State and by (ii) the first State (State of Residence of the company) waiving the $\operatorname{tax}$ on the distribution of the profits to the participants resident in the other State. The syntax of the sentence implies that both relief methods can be applied cumulatively.

\section{The example given by the Notes}

The Notes give the example of two natural persons, one of which is a resident of the Netherlands and the other of Belgium, starting up a Dutch general partnership ('v.o.f.') with an equal share for each partner. The

\section{Notes}

43 Art. 52 Belgian Company Code.

44 However, it should be noted that partners may opt to include in the partnership agreement that a resolution is required to distribute the profits.

45 Art. 205 and 206 Belgian Company Code.

46 Art. 204 Belgian Company Code.

47 N.H. de Vries and L.W. Sillevis, Cursus Belastingrecht (Vennootschapsbelasting), 1.0.6.A., Suppl. 244 (April 1996), p. 409.

48 D.A. van Waardenburg, Het nieuwe verdrag met België: enige hoofd- en vraagpunten, MBB 1971/7.

49 A. van Keulen, Een kwalificatie-probleem in het verdrag met België, WFR 1974/669.

50 H. Siebens, Het nieuwe verdrag met Belgie, MBB 1971/79.

51 As suggested by Art. 209 Belgian Company Code.

52 See also J.F.A. Jones, L. de Broe, M.J. Ellis and others, Characterization of Other States' Partnerships for Income Tax, Bulletin, July 2002 , para. 3.6, p. 310.

53 J. Ruysseveldt, De gewone commanditaire vennootschap, Kluwer België, 1997, p. 150; The annual accounts, including the profit allocation, of both the s.n.c. and s.c.s. have to be approved by the partners.

54 Contra with respect to the s.n.c.: B. Peeters, Het nieuwe Belgisch-Nederlands dubbelbelastingverdrag, Een artikelsgewijze bespreking, 2nd edition, 2002, p. 58; His opinion is based on the absence of capital divided into shares and the unlimited liability of the partners. 
business activities are carried on in Belgium. Although the Notes do not explicitly provide so, we must assume that the effective seat of management is located in Belgium, else Belgium would only be competent to tax the income of a permanent establishment, if any. Because the v.o.f. is a resident of Belgium, the Belgian tax law derogation of the civil law principles regarding legal personality, will not apply. ${ }^{55}$ According to the Notes, the v.o.f. is considered a Belgian company in the sense of article 3 of the Treaty. ${ }^{56}$ The profit of the v.o.f. will be taxed in Belgium at the standard corporate income tax rate $(33.99 \%$ at this point in time). From the Dutch perspective, the v.o.f. is transparent and the Dutch partner will be taxable on half of the income, on which the relief method of article 23, second paragraph, b of the Treaty will apply.

When the v.o.f. distributes profits, from a Belgian perspective a 25 percent withholding tax (hereinafter: 'WHT') will be due on the Belgian individual's share and a 15 percent WHT on the Dutch partner's share, following article 10 of the Treaty. From a Netherlands perspective, this WHT leads to legal double taxation on its resident, the first taxation on the 'permanent establishment' of the Dutch partner and a second tax on the distribution of the profits to the Netherlands. This double taxation can be avoided either by Belgium waiving the WHT on the dividend or by the Netherlands providing a credit for the Belgian WHT. The competent authorities of the Contracting States will decide in a mutual agreement procedure ex Article 28 Para. 3 of the Treaty which relief method will be applied.

\section{Analysis}

This example is surprising in many ways. If we accept the premise that the Dutch v.o.f. with its effective seat of management in Belgium will actually be regarded as opaque by Belgium, ${ }^{57}$ the two following remarks can be made. First, the second sentence of Art. 2, Protocol I, seems to imply that Belgium should accept the Netherlands transparency classification and treat the income as income ... of the participants of that company proportionate to their entitlement to the assets of the company.' If the latter provision is to be interpreted as a classification rule determining the taxing competence of the Contracting States, Belgium would only be able to tax the Netherlands partner of

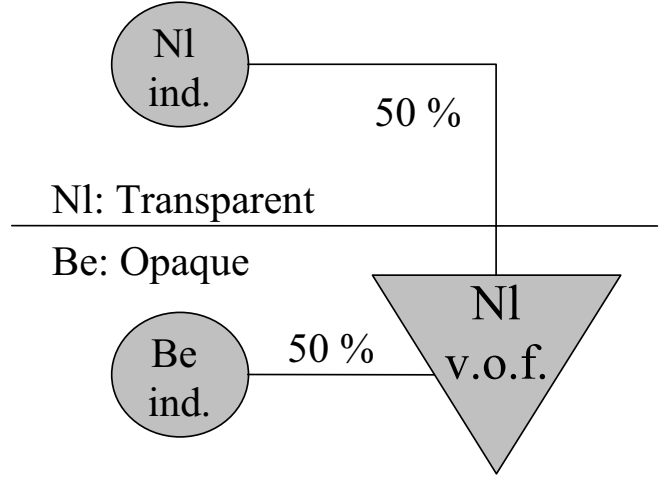

the Dutch v.o.f. when it has a PE in Belgium. As there is no mention of or allusion to this additional requirement, it appears the second sentence of Art. 2, Protocol I, is not meant to have such an effect. ${ }^{58}$ Moreover, since in the abovementioned example Belgium is not straight out prohibited from levying dividend withholding tax, it seems this provision is not to be taken into account for the application of Art. 10 of the Treaty. As a result, the exact scope of the provision remains unclear. A final remark concerns the cumulative applicability of the two relief methods. It seems, notwithstanding the clear syntax of the third sentence of Art. 2, Protocol I, that only one method will apply and it will be left to the competent authorities to decide which one. This suggests that an entity seeking relief in this situation is required to start the mutual agreement procedure of article 28 of the Treaty.

\section{Comparison with the OECD partnership report}

The example outlined in the Notes is almost identical to example 18 of the OECD report. According to the Report, the classification conflict raises three difficulties with respect to the elimination of double taxation. Applied to the case at hand, these are:

1. the fact that Belgium taxes two different events, the earning of profits and their distribution, while the Netherlands will only tax one event, being the earning of profits;

2. the timing mismatch that could result from the fact that Belgium taxes the distribution a year later than the Netherlands; and

\section{Notes}

55 See Heading 4.B.1.

56 We already contended above that in our view, a Dutch v.o.f. is to be treated as transparent from a Belgian perspective as well. In the case at hand, an even stronger objection is to be made against the proposition that Belgium would see the v.o.f. as opaque. In its international private law, Belgium applies the law of the country where the effective seat of management is located in order to determine legal personality. As already mentioned, tax law follows civil law in Belgium. The example given presupposes that the effective seat of management is in Belgium; if not, Belgium would not be competent to tax the dividend distribution at all. Consequently, Belgium will only have to look at its own company law in order to determine whether the entity has legal personality. If the v.o.f. has not taken the form of a Belgian legal person, which always requires some kind of formal procedure, it will not have legal existence in Belgium and be transparent. On the other hand, if the entity did follow a procedure to become a legal person in Belgium, it will be incorporated in Belgium from that moment onwards. The Netherlands will now see the entity as a Belgian company. In conclusion, a correct application of Belgian international private law to this example will prevent the entity from becoming hybrid so that the Protocol provision is not applicable.

57 What we have contradicted under Heading 4.B.2.

58 G.K. Fibbe en J.L. Van De Streek, 'Enkele kanttekeningen by de protocolbepalingen van het nieuwe verdrag met België inzake hybride entiteiten', WFR 2003/695, p. 699; J.F.A. Jones, L. De Broe, M.J. Ellis and others, l.c., IBFD Bulletin, July 2002, para. 4.3, p. 318 contra: J.W. Bellingwout, 'Dividend, rente en vermogenswinst in het nieuwe belastingverdrag met België, Weekblad, 2001/5453, p. 1450. 
3. the fact that Belgian tax is levied on the partnership as a legal entity while the Netherlands tax is levied on the partners.

Regarding the first two problems, the OECD approach is quite different from that taken by the Treaty partners. The Report does not seem to have a problem with the profit taxation and subsequent taxation of the distribution by Belgium in this case. The Netherlands should only be required to exempt or give a credit for the business profits derived from Belgium. The Report simply submits that the Netherlands would not be able to tax the dividend distribution since the partnership is transparent from the Dutch viewpoint. Accordingly, the Netherlands would not be able to give a credit for the dividend withholding tax..$^{59}$

In contrast, the Notes explicitly take notice of the legal double taxation that arises from the viewpoint of the Netherlands. As the Netherlands only considers the partners and ignores the partnership as a legal entity, the partner's profits are being taxed twice in Belgium; once as a profit and a second time upon distribution of that profit. In this respect, it appears the Treaty partners have reached a more thorough solution than is submitted by the OECD.

Regarding the third difficulty, the Notes, contrary to Lang, take the position that the transparency approach is to prevail over the entity approach. According to Lang, also the business profits of the partnership should fall under Art. 10 of the OECD Model Tax Convention as income from corporate rights. ${ }^{60}$ Under that hypothesis, the Netherlands should have the residual taxing rights and Belgium's taxing power would be limited to the percentage provided for in Art. 10. However, it is difficult to see how the business profits could in any case qualify as income from corporate rights'. From the Belgian perspective, the business profits constitute income of the corporation itself and not of its shareholders and from the Netherlands perspective, there simply is no legal entity.

Overall, the position of the Contracting States seems well balanced and defendable. In this light, it is even more regrettable the Notes suggest it is necessary to rely on the competent authority procedure to find the right means to prevent the double taxation.

\section{B. Initiative of the partnership (Art. 4, subpart b, Protocol I)}

\section{The Protocol provision}

This provision, aimed at ensuring Treaty rights for hybrid entities, reads as follows:
'If a company is not subject to tax as such in one Contracting State and is subject to tax as such in the other Contracting State, on request of the company, the provisions of sections III, IV and V of the Treaty will be applied by the other Contracting State to the extent they should have been applied if the participants in the company's capital had received the income directly or owned the capital of the company directly, each to the extent of its share in the company. The application of the former sentence does not prevent the other Contracting State to determine the taxable base according to its national law and only reduces this insofar as results directly from the former sentence.'

\section{The example given by the Notes}

The Joint Explanatory Notes provide an example of the application of this provision. ${ }^{61}$ A Dutch individual and a Dutch b.v., both residents in the Netherlands, are partners in a Dutch v.o.f. Each of the partners is entitled to the partnerships assets for fifty percent. The business of the company is effectively carried on in the Netherlands. ${ }^{62}$ The v.o.f. holds a 20 percent stake in the share capital of a Belgian resident b.v.b.a.. The b.v.b.a. distributes a dividend. From the Belgian perspective, the Dutch v.o.f. is opaque yet Art. 10 of the Treaty is not applicable since the partnership is not subject to Dutch taxation and therefore does not qualify as a resident according to Articles 1 and 4 of the Treaty. The Dutch partners cannot enjoy Treaty benefits either as they are not the beneficiaries of the dividend from the Belgian perspective. Belgium would levy the standard withholding tax of 25 percent on the profits distributed by the b.v.b.a.

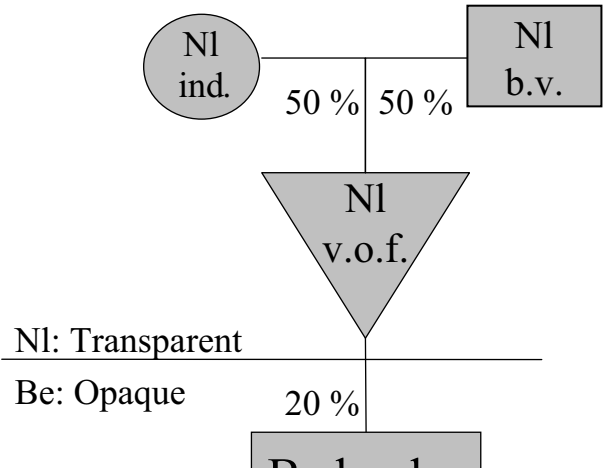

Be b.v.b.a

\section{Notes}

59 The Report, paragraphs 136 and 137 . However, under the 2003 Belgium-Netherlands tax Treaty one could argue that the Netherlands should keep open the possibility under the Competent Authority Procedure to give a credit as suggested by the Notes, even if this would be in conflict with Dutch domestic law.

60 M. Lang, A Critical Analysis of the Report Prepared by the OECD Committee on Fiscal Affairs, Kluwer Law International, 2000, p. 97.

61 Kamerstukken II, 2001-2002, 28259, nr. 3 at 23.

62 We presume that the management and control is equally situated in the Netherlands. 


\section{Analysis}

Art. 4(b), Protocol I includes that the v.o.f. may opt in Belgium to grant the Treaty benefits of Art. 10 to the v.o.f. and reduce the withholding tax to the extent as if the dividends were paid directly to the partners. In the abovementioned example, this would lower the withholding tax rate to 10 percent. ${ }^{63}$ It should be observed that this final percentage is limited to this particular case. Every distinct division of the shares in the v.o.f. between the b.v. and the individual will result in another final withholding tax rate. The rationale of this aggregated percentage seems to be that from the Belgian accounting law perspective only the participation of the v.o.f. is visible 64 and it is impossible reportingwise to split up the dividends in order to apply different withholding tax rates for the two Dutch partners.

It should be noted that Art. 4(b), Protocol I only applies to companies. However, from the Dutch perspective, the v.o.f. is not a company in the meaning of Art.3 (1)(c) of the Treaty as it is not a body corporate or an entity treated as a body corporate for Dutch taxation purposes. On the other hand, the scope of Art. 4(b), Protocol I is determined by the requirement that the provision applies to companies that are not subject to tax as such in one Contracting State and are subject to tax as such in the other Contracting State. Therefore, considering this requirement and the abovementioned example, the context outlined by the Joint Explanatory Notes seems to require that the definition of the term 'company' is no to be applied in this respect. ${ }^{65}$

\section{Comparison with the OECD partnership approach}

The solution provided for by Art. 4(b), Protocol I is comparable to the one suggested in Para. 8.4 of the revised 2000 Commentary on Art. 4 of the OECD Model Tax Convention. This paragraph suggests that where a State disregards a partnership for tax purposes and treats it as fiscally transparent, the partners are the appropriate persons to claim the benefits of the Convention concluded by the State of which they are residents since the income of the partnership flows through the partnership to the partners and they are liable to tax on that income under the domestic law of that State. A difference between Art. 4(b), Protocol I and the OECD approach is that under Art. 4(b) it is the partnership itself that has the competence to opt for this treatment. As mentioned above, the rationale of one aggregated percentage seems to be of a practical nature. The OECD approach also covers partners residing in third States. Due to the bilateral character of the Belgium-Netherlands tax Treaty, the scope of Art. 4(b) is limited to resident partners in the Netherlands and Belgium. However, it should be noted that in 1997 a Decree was issued by the Dutch Ministry of Finance in which this approach, provided certain conditions are met, was extended to partners residing in third States. ${ }^{66}$ As Belgium did not make any observations to the Partnership report, it can be presumed it would also follow the OECD approach.

\section{Relationship between the two Protocol provisions}

The relationship between the two Protocol provisions discussed is far from clear. ${ }^{67}$ Based on the example given, Art. 2, Protocol I seems only applicable after the allocative provisions have been applied and double taxation or double exemption still results. The Joint Explanatory Notes state that the competent authorities will decide which method of relief will be appropriate. Both of these considerations indicate it was not the negotiators' intention for Art. 2, Protocol I, to have direct effect. They imply that the provision is merely a statement of cause for remedying double taxation, to be applied by the competent authorities on a case-bycase basis. ${ }^{68}$ On the other hand, Art. 4(b), Protocol I clearly allows the hybrid entity to invoke Treaty articles to the benefit of its partners without having to rely on a mutual agreement procedure. Its direct effect cannot be doubted.

The wording of Art. 4(b), Protocol I seems to imply that this provision could also prevent Belgium to levy dividend withholding tax in the example given in Heading 5.A.2. If on request of the v.o.f., the provisions of sections III of the Treaty would have been applied by the other Contracting State (in the example at hand: Belgium) to the extent they should have been applied if the partners in the v.o.f. had received the income directly, a dividend withholding tax would no longer be possible. Based on Art. 10, Para. 1 of the Treaty, the income can no longer be considered as 'dividends paid by a company' since income is now considered to be received directly by the partners for Treaty purposes. However, it can also be defended based on the example given in Heading 5.B.2,

\section{Notes}

635 WHT on the $50 \%$ interest of the BV $(2.5 \%)$ and $15 \%$ WHT on the $50 \%$ interest of the individual $(7.5 \%)$. Adding these two percentages results in the final percentage of $10 \%$.

64 Shareholders in a b.v.b.a. are registered by name.

65 See also J.F.A. Jones, L. de Broe, M.J. Ellis and others, Characterization of Other States' Partnerships for Income Tax, Bulletin, July 2002, Para. 4.3, p. 318 and F.A. Engelen and A.J.A. Stevens, De behandeling van personenvennootschappen onder het nieuwe verdrag met België, Maanblad Belastingbeschouwingen, 2003, nr. 4, p. 120.

66 Decree of 19 March 1997, no. IFZ97/204 and the Decree of 24 April 2001, no. IFZ2001/327M.

67 J.F.A. Jones, L. de Broe, M.J. Ellis and others, Characterization of Other States' Partnerships for Income Tax, Bulletin, July 2002 , para. 4.3, p. 319.

68 An agreement reached in such a mutual agreement procedure is to be published and will be binding in similar cases according to Art. 3, Protocol I. 
that Art. 4(b) Protocol I is only applicable to situations where a company is not subject to tax as such in the State where it is a 'resident' and is subject to tax as such in the State where it generates income. ${ }^{69}$ In that supposition, the provision would not be applicable in situations as in Heading 5.A.2. However, there are no grounds mentioned in the text of the provision for such an interpretation.

\section{The limited partnership provision (Art.10, §7)}

The Joint Explanatory Notes mention that this provision was introduced to prevent certain items of income being taxed twice or less than once as a consequence of classification conflicts. In this respect, it is mentioned that Art. $10 \$ 7$ supplements Art. 2, Protocol I. Art. $10 \$ 7$ reads as follows:

'Income earned as a silent (limited) partner from profit shares in an enterprise of one of the Contracting States may be taxed in that State according to its laws'.

This provision allocates taxing jurisdiction for the limited partner's profit share to the Contracting State where the limited partnership is located, regardless of its classification as transparent or opaque. According to the Joint Explanatory Notes, Art. $10 \$ 7$ is to be applied exclusively with respect to income earned as a limited partner from profit shares in an enterprise of one of the Contracting States. This means that the provisions of articles $5,7,10 \$ 1$ till $\$ 6$ and 11 are not applicable to this kind of income. Subsequently, the resident State of the partner will have to give relief according to Art. 23 of the Treaty irrespective of the characterization of the income under the laws of that State. In other words, the Resident State of the partnership (the partnership's enterprise is to be carried on by a resident of that State, art. 3 Para. 1, under $\mathrm{d}$, of the Treaty) has the exclusive taxing jurisdiction of the profit share of the limited partner.
The relationship of this provision with Art. 2, Protocol I is rather vague. ${ }^{70}$ With respect to the example under Heading 5.A.2, the outcome seems to be considerably different if the Dutch v.o.f. was replaced by a Dutch c.v. (or Belgian s.c.s.). According to Art. $10 \$ 7$, Belgium has the full taxing right on the dividends paid to the Netherlands partner and does not have to refrain from dividend withholding tax as seemed to be the consequence of Art. 2, Protocol I as applied to the v.o.f. Moreover, since the Joint Explanatory Notes mention that Art. $10 \$ 7$ is to be applied exclusively and the provisions of Art. $10 \$ 1$ till $\$ 6$ are not applicable, the withholding tax is not limited by the Treaty. Following the Joint Explanatory Notes, the Netherlands will subsequently have to give relief in accordance with Art. 23 of the Treaty.

\section{Conclusion}

In the 2003 Belgium-Netherlands tax Treaty, three provisions have been included relating to partnerships that implement a considerably different approach than the 1970 Treaty where (Dutch) partnerships were considered Treaty residents by virtue of a specific Treaty provision. Under the new Tax Treaty, two provisions relating to hybrid entities in general and one relating to limited partnerships specifically have been included. It is an interesting development in international policy that so much attention was given in the Treaty and in the Explanatory Notes to the classification conflicts inherent to partnerships. Nevertheless, not all aspects of the new provisions are clear, especially the scope and the interrelationship between the provisions remain somewhat obscure. Also the differing treatment of the general and the limited partnership is an impediment to the internal consistency of the new Treaty. Hence, it seems recommendable for future tax Treaty policy to realign the content of these provisions in order to present the taxpayer with a more consistent and comprehensive approach to remedying double taxation.

\section{Notes}

69 F.A. Engelen and A.J.A. Stevens, De behandeling van personenvennootschappen onder het nieuwe verdrag met België, Maanblad Belastingbeschouwingen, 2003, nr. 4, p. 121.

70 F.A. Engelen and A.J.A. Stevens, l.c., Maanblad Belastingbeschouwingen, 2003, nr. 4, p. 125. 